\title{
Impact of Environmental Disclosure on Firm Performance: An Empirical Analysis of Food, Beverage and Tobacco Sector Companies Listed in Colombo Stock Exchange, Sri Lanka
}

Menike, L. M. C. S.

To Link this Article: http://dx.doi.org/10.6007/IJARBSS/v10-i10/7977

DOI:10.6007/IJARBSS/v10-i10/7977

Received: 08 July 2020, Revised: 11 August 2020, Accepted: 15 September 2020

Published Online: 02 October 2020

In-Text Citation: (Menike, 2020)

To Cite this Article: Menike, L. M. C. S. (2020). Impact of Environmental Disclosure on Firm Performance: An Empirical Analysis of Food, Beverage and Tobacco Sector Companies Listed in Colombo Stock Exchange, Sri Lanka. International Journal of Academic Research in Business and Social Sciences. 10(10), 518-536.

\section{Copyright: (c) 2020 The Author(s)}

Published by Human Resource Management Academic Research Society (www.hrmars.com)

This article is published under the Creative Commons Attribution (CC BY 4.0) license. Anyone may reproduce, distribute, translate and create derivative works of this article (for both commercial and non-commercial purposes), subject to full attribution to the original publication and authors. The full terms of this license may be seen at: http://creativecommons.org/licences/by/4.0/legalcode

\section{Vol. 10, No. 10, 2020, Pg. 518 - 536}




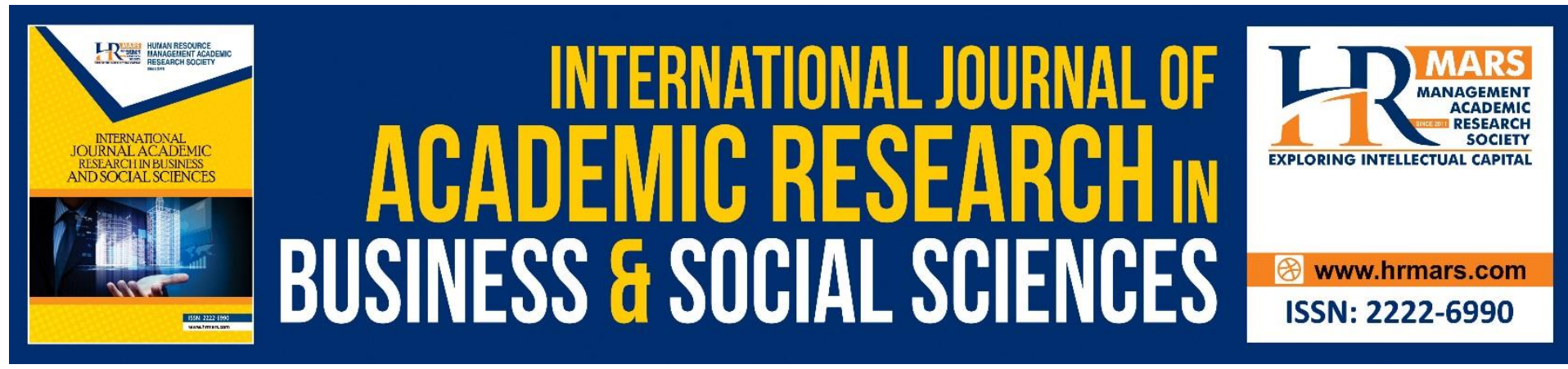

\title{
Impact of Environmental Disclosure on Firm Performance: An Empirical Analysis of Food, Beverage and Tobacco Sector Companies Listed in Colombo Stock Exchange, Sri Lanka
}

\author{
Menike, L. M. C. S. \\ Department of Accountancy and Finance, Faculty of Management Studies, Sabaragamuwa \\ University of Sri Lanka, Belihuloya. Sri Lanka \\ Email: Imcsmenike@gmail.com
}

\section{Abstract}

In recent years, environmental accounting disclosure has become more important in the business community as they are accountable to comply with the environment highly in which they operate. A cleaner and greener environment is a must for every business to survive in the business world saving the planet. The primary objective of an organization is to maximize the shareholders' value; hence it is needed to know the additional value created through adopting environmental accounting disclosures by the companies. Therefore, this study investigates, the impact of environmental disclosure on firm performance of food, beverage, and tobacco sector companies listed on the Colombo Stock Exchange. The data were collected from the annual reports of twenty-six (26) companies for the period from 2012 to 2019. An indexing procedure is used to measure the contents of the disclosures and 19 items of information were selected for inclusion in the disclosure index, the proxy for environmental disclosure. The firm performance was measured by using a proxy, Return on Assets. Firm size and liquidity were considered as the control variables. The study applied a panel data regression procedure. The results show that environmental accounting disclosure and firm size had a significant positive impact on return on assets. However, the liquidity could not show any significant relationship with return on assets. The finding will give an incentive for managers to adopt environment-friendly resources/activities to satisfy the stakeholders' expectations and save the earth. The top management should make sure that they comply with the environmental laws as a long-term business strategy in enhancing sustainability.

Keywords: Colombo Stock Exchange, Content Analysis, Environmental Accounting Disclosure, Firm Performance, Panel Data Regression

\section{Introduction}

Global warming and climate change are the most crucial environmental issues experience by the business world. In recent years, environmental accounting disclosure has become more important among the business community as it is an element of disclosure of corporate social responsibility (CSR). The meaning of environmental accounting is to achieve sustainable growth and development and foremost to maintain the relationship between the community 
(Ministry of the Environment, 2005). Environmental accounting is on developing and expanding as the social focus on the environment is increasing, thus, it enhances the expectation in measuring the environment (Mahenna et al, 2004). International Organization for Standardization (ISO) had introduced the ISO 14000 series of standards which includes various aspects of environmental management as it provided practical tools for companies to enhance their environmental performance as well as lead to an increase in the company's productivity and success (Abdullah \& Fuong, 2010).

Companies are fully aware of the environment as a business issue and have realized the value of environmental responsibility in addition to their primary purpose of maximizing profit (Palmer et al., 2018). Globally, there is enormous importance of proper disclosing of environmental accounting disclosure to business organization, hosting community, other stakeholders, and nations at large (Chinedu \& Ogochukwu, 2020). Therefore, environmental reporting practices by various organizations around the world have grown significantly in recent years (Kihamba, 2017). With the expansion of industrial-based market economic activities, various adverse environmental impacts may be associated with them. All organizations should have a greater understanding of the interaction between the companies and the environment in which they operate (Adediran \& Alade, 2013).

Some studies have empirically analyzed the impact of corporate environmental performance on financial performance ( Konar \& Cohen, 2001; Egbunike \& Okoro, 2018). The traditional perspective considers environmental costs companies' resources as end-of-pipe treatment or pollution prevention efforts (Filbeck \& Gorman, 2004). When applying for environmental permits, companies spend billions of dollars annually on the technologies necessary to install compulsory technologies or to comply with environmental pollution (Portney et al., 2000). The ultimate goal of such a significant cost is to improve financial performance and maximize profits and wealth (Konar \& Cohen, 2001).

There is widespread evidence that environmental information is useful for decisionmaking by investors and other stakeholders (Richardson \& Welker, 2001). In response to the concerns of investors and other stakeholders on corporate environmental policy, many companies are voluntarily increasing their social and environmental disclosures through various sources and media. As a result, several companies around the world disclose such information in the form of periodic environmental reports, which are issued separately from the annual financial reports (Bewley \& Li, 2000; Rajapakse, 2002).

Since 1977, with the open economy, both local and multinational companies are remarkedly increasing contributing largely to economic growth. However, due to rapid industrialization, the adverse impacts on the environment have been growing as a result of disposing of industrial wastes, burning fossils fuels, deforestations, intense usage of lands, water pollution, biochemical wastes which make the biotic components of the earth vulnerable. A survey by the Central Environmental Authority (CEA) of Sri Lanka shows that there are 119 highly polluting factories in Colombo and rural areas (Rajapakse, 2002). Thus, businesses are accountable to comply with the environment highly in which they operate, and whereas the stakeholders have the right to demand information about the environmental resources consumed by them through their operating activities, hence it is required to disclose such in Annual Reports. However, statutory or professional requirements for environmental reporting in Sri Lanka are not mandatory and environmental reporting is mainly voluntary. 
The stakeholders' awareness of the environmental impact of industrialization in Sri Lanka is widely spread in recent years. Rajapaksa (2008) reports that the majority of Sri Lankan stakeholders (52\%) are aware of the environmental management practices of business organizations and is well aware of its environmental impact as well. Further, there is not much indication that the environmental disclosures are substantially enhanced in the annual reports of public listed companies in Sri Lanka. The primary objective of an organization is to maximize the shareholders' value; hence it is needed to know the additional value created through adopting environmental accounting disclosures by the companies. Thus, an investigation of the measurement of environmental performance and its impact on firm performance is an area of concern so that companies compel to adopt more environmental disclosure practices.

Moreover, companies maximize their profits by considering the visible costs and do not pay much attention to hidden environmental costs. However, to ensure profit maximization and survive in the business world, they should adopt proper strategies to overcome the potential environmental problems that occur in the locations where the operations are taken place. Şenol \& Ozcelik (2012) also argue that, if companies have a proper system to record environmental accounting disclosure, it leads to cost minimization and additional income in long term.

As revealed in the above discussion, environmental accounting disclosure is a significant factor that determines the firm profitability and it has been affirmed by most of the previous empirical studies. However, the attention given to this area is low in the Sri Lankan context. Thus, the objective of this study is to investigate, the impact of environment accounting disclosure on firm performance in Food, Beverage, and Tobacco sector companies listed in CSE, Sri Lanka. The environmental accounting disclosure practices were measured by computing an environmental accounting disclosure index and firm performance was measured by using a proxy such as return on assets. The findings of this study will give benefits to various parties.

\section{Literature Review \\ Empirical Review}

Financial reporting provides a variety of information and stakeholders are increasingly paying more attention to environmental issues related to financial performance. Thus, plenty of researchers have focused on the relationship between financial performance and environmental disclosure and have reported mixed results. Klassen \& McLaughlin (1996) established a linkage between environmental management practices and improved future financial performance and discover a significant positive financial return for strong environmental management while significant negative financial returns for weak environmental management. Firms with a higher pollution propensity and greater media coverage of their environmental performance are more likely to disclose general environmental information in Canadian manufacturing firms (Bewley, \& Li, 2000). Salama (2005); Montabon, Sroufe \& Narasimhan (2007) establish a significant positive relationship between environmental management practices and measures of firm performance.

Razeed (2009) argues that the firm's economic performance (measured by profitability) is important in the decision to be made in environmental disclosure. Joshi et al. (2011), found an important inverse relationship between company profitability and environmental disclosure. However, Makori (2013) shows that results on company profitability and environmental accounting seem to be mixed. Adediran \& Alade (2013) used multiple 
regression analysis of 14 randomly selected companies quoted on the Nigerian Stock Exchange and show that environmental accounting had a positive relationship with net profit margin, dividend per share, and a negative relationship with return on capital employed and earnings per share. Najah \& Jarboui (2013) explore the effect of voluntary environmental disclosure on a firm's financial performance in French organizations and results demonstrated that there is no relationship between environmental disclosure and financial performance. Muhammad, Scrimgeour, Reddy \& Abidin (2015) found a positive relationship between environmental performance and financial performance during the pre-financial crisis period (2001-2007) and no association between environmental and financial performances in the financial crisis period (2008-2010) in Australia. Environmental and social costs significantly affect net profit margin, return on capital employed, and earnings per share of manufacturing companies (Ihendinihu \& Okafor, 2016).

Nurhasimah, Nurhabibi, Nor, Sheh \& Inaliah (2016) examined the impact of environmental disclosure on financial performance among the top 100 market capitalization companies in Malaysia for the year 2011. Return on assets (ROA), profit margin, return on equity (ROE), and also Earnings per share (EPS) used to measure financial performance. The results revealed that there is a significant relationship between profit margin and total environmental disclosure whereas ROA, EPS, and ROE could not show any significant relationship on total environmental disclosures.

Kihamba (2017) finds a positive relationship between profitability measured by ROA and environmental accounting disclosure, leverage, and liquidity where the leverage and liquidity are the control variables. There exists a relationship between environmental accounting disclosures and earnings per share and return on equity in food and beverage companies in Nigeria (Ezeagba, Rachael \& Chiamaka, 2017). Egbunike \& Okoro (2018) used community participation expenses and the amount spent on environmental protection to measure green accounting and return on capital and Tobin $Q$ as indicators of financial performance and confirm no significant relationship between profitability and green accounting measures among non-consumer goods companies. Chinedu \& Ogochukwu (2020) identify a critical and positive relationship between environmental accounting disclosure and earnings per share, return on assets, net profit margin, firm's age, and audit firm type.

The above literature review highlights the relationship between environmental accounting disclosure and firm profitability in developed countries and several studies concentrated on developing countries as well. The results are not consistent over countries and are country-specific; For instance, population density, geographical location, environmental laws, and stock market regulations, policy implications are all country-specific. Moreover, it is argued that corporate environmental disclosures are not applicable for companies universally as the companies are at different stages of economic development and their motivation and attitudes towards corporate environmental disclosure will differ. This requires a country-specific study and this study seeks to investigate the environmental reporting disclosure and firms performance in Sri Lanka.

\section{Theoretical Background}

\section{Stakeholders Theory}

The stakeholders' theory concentrates on the foundations of communication between the various stakeholders and it asserts that the firm's success depends on the successful 
management of all the relationships that a firm has with its stakeholders- a term originally introduced by Stanford Research Institute (SRI) to refer to those groups without whose support the organization would cease to exist (Freeman, 1983). The theory asserts that managers must satisfy a variety of constituents (example, employees, customers, suppliers, local community, and so on) who can influence the firm's outcomes and guide the managers to engage in certain environmental activities in which non-financial stakeholders perceive important if not, these groups might withdraw their support from the business. Stakeholders play an important role in an organization because they have direct control over the resources necessary to carry out the activity (Ullmann, 1985). Freeman (1983) incorporates the stakeholders' concept into two categories: (i) A business planning and policy model, and (ii) A corporate social responsibility model of stakeholder management.

The first model focuses on developing and evaluating the approval of corporate strategy decisions by groups whose support is required for the firm's continued existence. The stakeholders identified in this model include the owners, customers, public groups, and suppliers. Although these groups are not adversarial in nature, their possibly conflicting behavior is considered a constant on the strategy developed by management to best match their firm's resources with the environment (Deegan and Gordon, 1996). The second model covers to include external influences that may be adversarial to the firm and include the regulatory environmentalist and/or special interest groups concerned with social issues (Guthrie and parker, 1990). This model permits managers and accountants to consider a strategic plan that is adaptable to change in the social demands of non -traditional stakeholder groups. The stakeholders' theory proposed an increased level of environmental awareness which creates the need for companies to extend their corporate planning to include non-traditional stakeholders like the regulatory adversarial groups to adapt to changing social demands (Trotman, 1999). The main concern of the stakeholders' theory in environmental accounting is to address the environmental cost elements and valuation and its inclusion in the financial statements.

This study is based on stakeholders' theory, as it guides the managers to adopt environmental practices that the non- financial stakeholders might think enormous important to maximize stakeholders' value by minimizing environmental costs.

\section{Research Hypotheses \\ Environmental Disclosure Index}

A large number of scholars have investigated the relationship between environmental accounting disclosure and firm performance in both developed and developing countries. Najah \& Jarboui (2013) explore the effect of voluntary environmental disclosure on a firm's financial performance and find that there is no relationship between environmental disclosure and return on assets in French organizations. Nor et al. (2016) examined the impact of environmental disclosure on financial performance among the top 100 market capitalization companies in Malaysia and they report there does not exist any significant impact on return on assets. Rakiv et al. (2016) find a significant positive relationship between disclosure of environmental accounting reports and return on assets of listed manufacturing companies in Bangladesh. The environmental accounting disclosure had a significant positive relation on ROA in manufacturing listed companies on the Nairobi Securities Exchange (Kihamba, 2017). It is proved a positive relationship between environmental accounting disclosure and return on assets in Nigerian manufacturing firms (Chinedu \& Ogochukwu, 
2020). Thus, based on the above-mentioned arguments, it is proposed the following hypothesis.

\section{H1: There is a significant positive relationship between environmental accounting disclosure and firm performance}

\section{Firm Size}

Firm size is a scale in which the firms are classified in different ways such as total assets, size of stock market value, and the number of employees. Environmental disclosure in annual reports largely depends on the size of the firms. The general public is well aware of large companies thus, they will disclose more information as they have greater resources and social responsibility to the community as a whole. Firm size has been found to have a significant positive relationship with social disclosure (Burke et al., 1986; Blacconiere \& Patten, 1994). Larger firms tend to demonstrate better pollution control performance to respond to what stakeholders expect. Size is thus a proxy for political sensitivity (Watts \& Zimmerman, 1986). The firms that disclose environmental information are larger in size (Belkaoui \& Karpik, (1989). Najah \& Jarboui (2013) emphasizes that larger firms are more profitable than smaller firms. On the contrary, Orlitzky (2001) states that the firm size does not impact on firms' profitability. Kihamba (2017) and Serrasqueiro \& Nunes (2014) propose that there is a positive relationship between firm size and profitability, hence the study proposes the following hypothesis.

\section{H2: Firm size impacts positively on firm performance}

\section{Liquidity}

Liquidity refers to the ability of a firm to meet its short-term obligations. A firm that has sufficient liquidity will efficiently meet the liabilities when they due hence, maintain a good rapport with loyal customers and vendors, and ensures increased sales thereby greater economic performance in short term and long run as well. Liquidity portrays the capacity of a firm to acquire more assets that generate cash and to settle obligations when they become due without incurring any losses. The high liquidity level shows a credible company's ability to generate a strong image that allows stakeholders to always rely on the company that leads to efficient economic performance. Scholars find positive relationships between liquidity and firm profitability (Muhammad et al., 2015; Kihamba, 2017). Coleman (2010) and Ingumba (2017) considered the liquidity as a control variable and measured as the proportion of current assets for current liabilities. Thus, it is formulated the following hypothesis.

\section{H3: There is a significant positive relationship between liquidity and firm performance.}

\section{Methodology The Data}

The data for 26 companies out of 50 listed companies in the Food, Beverage, and Tobacco sector in CSE as of the end of 2019 were obtained from the annual reports of individual companies. The sample covers financial statement data from 2012 to 2019 . Environmentallydisclosed information was obtained from the annual reports using content analysis. The highest level of the environmental disclosure items is reported under sustainability reporting and the next level of disclosure is under the CEO reports and the vision, mission, and value statements. The sample was selected based on several criteria; The firms whose financial 
statements do not provide sufficient environmental disclosures, the firms delisted and newly listed during the sample period 2012-2019, companies whose trading had not been occurred at least once a month, and the companies whose fiscal year ended in December 31st were excluded from the study.

\section{Content Analysis}

Content analysis is the main method used to examine environmental disclosures in annual reports (Wiseman, 1982:Freedman \& Jaggi, 1992; Gray et al., 1995; Hackston \& Milne, 1996; Guthrie \& Abeysekera, 2006). The content analysis method used in this study was based on the methods used by Wiseman (1982) and Freedman \& Jaggi (1992). An indexing procedure is used to measure the contents of the disclosures and 19 items of information were selected for inclusion in the disclosure index. Based on Wiseman (1982) this study was taken 18 items from these 19 items and added another newer environmentally-related factor as "Energy conservation" under the "Pollution abatement" category based on Jariya (2015) and Rajapakse (2003). A rating sheet was developed to measure the extent of disclosure which was classified into four categories. The first category covers the items directly related to economic factors; the second category embodies items relating to environmental litigation; the third category included pollution abatement items and category four contains other elements related to the environment that did not come under any of the previous categories. A list of the 19 items by category is attached in Appendix A. Rating of the disclosures was based on the presence or absence and the degree of specificity of each of the information items. A score of three was assigned to an item if it was present in the disclosure and was described in monetary or quantitative terms. This mean environmental impact was clearly defined in monetary terms of actual physical quantities. This was the maximum possible score for an item since monetary or quantitative measures are recommended as the preferred disclosure form. An item was given a score of two if it was presented in the disclosure with the impact of the company or its policies were evident (non-quantitative terms). A score of one was assigned to items mentioned only in general terms (Vague). A score of zero was allowed if the item was not presented in the disclosure. This weighting is consistent with that used by Freedman \& Jaggi (1992) and Wiseman (1982). Finally, the overall environmental disclosure index can be figured by calculating the percentage of a total score out of the total possible score gained by the particular company. In this research total, the possible score is $57(19 * 3)$.

\section{Model Specification Panel Data}

To investigate the impact of environmental disclosure and firm performance of listed companies in the Food, Beverage, and Tobacco sector a panel data regression procedure is applied which examines individual effect, time effect, or both and these effects are either fixed or random. A fixed-effect model examines whether the intercepts vary across individuals (groups) or periods, whereas a random effect model explores differences in error variance

\section{Fixed Effect Model}

In the fixed-effect model, the group effect, or time effect, or both are entered in the model through dummy variables. For example, if only the group effect is entered in the model it can be written as:

$$
Y_{i t}=\propto+\mu_{i}+X_{i t}^{T} \beta+\epsilon_{i t}
$$


Where $\alpha$ is the intercept, $\mu_{\mathrm{i}}$ is the $\mathrm{i}^{\text {th }}$ group effect, $\mathrm{X}_{\mathrm{it}}$ is a vector of predictors and $\varepsilon_{i \mathrm{t}}$ is the error term. Further, we assume that

$$
\epsilon_{i} \sim N\left(0, \sigma^{2}\right)
$$

The group effect, $\mu_{i}$, to be included in the model through the dummy variables. That is, for $n$ number of groups, $(n-1)$ number of dummy variables $\left(d_{1}, d_{2}, \ldots ., d_{n-1}\right)$ to be introduced. Then the model (2) can be written as,

$$
Y_{i t}=\propto+\gamma_{1} d_{1}+\gamma_{2} d_{2}+\cdots \ldots \ldots .+\gamma_{n-1} d_{n-1}+X_{i t}^{T} \beta+\epsilon_{i t}
$$

The significance of the group effect in the fixed effect model can be tested using the $F$ -

test.

Hypothesis:

$\mathrm{H}_{0}: \gamma_{1}=\gamma_{2}=\ldots \ldots \ldots \ldots \ldots . . . .=\gamma_{n-1}=0$

$\mathrm{H}_{\mathrm{a}}$ : at least one group effect is not different from zero.

Similarly, the fixed time effect model can be obtained by including the dummy variable for the period considered instead of the group dummies in the model (2). Further, the fixed time and group effect model can be obtained by including dummies for groups as well as for time. The model takes the form.

$$
Y_{i t}=\propto+\mu_{i}+T_{t}+\cdots \ldots \ldots .+X_{i t}^{T} \beta+\epsilon_{i t}
$$

Where $T_{t}$ represents the time effect.

\section{Random Effect Model}

In the fixed-effect model, the mean component is decomposed into group effect and/or time effect and effect from other predictor variables. However, in the random effect model, the variability is separated due to the group effect, time effect, and error. That is, we estimate variance components for groups (or time) and error. Thus, explore differences in error variances.

The functional form for the random group effect model is

$Y_{i t}=\propto+X_{i t}^{T} \beta+u_{i}+\epsilon_{i t} \quad$ and

$u_{i} \sim N\left(0, \sigma_{g}^{2}\right)$

$\epsilon_{i t} \sim N\left(0, \sigma^{2}\right)$

Similarly, the functional form for the random time effect model is

$Y_{i t}=\propto+X_{i t}^{T} \beta+v_{t}+\epsilon_{i t} \quad$ and

$v_{t} \sim N\left(0, \sigma_{T}^{2}\right)$

$$
\epsilon_{i t} \sim N\left(0, \sigma^{2}\right)
$$

The two-way random effect model for time and group can be expressed as

$Y_{i t}=\propto+X_{i t}^{T} \beta+u_{i}+v_{t}+\epsilon_{i t} \quad$ and

$$
\begin{aligned}
v_{t} & \sim N\left(0, \sigma_{T}^{2}\right) \longrightarrow(6) \\
\epsilon_{i t} & \sim N\left(0, \sigma^{2}\right)
\end{aligned}
$$

The parameter in the random effect model can be estimated by generalized least squares (GLS) when the variance structure $\left(\sigma_{g}^{2}, \sigma_{T}^{2}\right.$ and $\left.\sigma^{2}\right)$ is known and by feasible generalized least square (FGLS) when the variance structure is unknown. Compared to the fixed-effect model, 
the random effect models are relatively difficult to estimate due to the complex correlation structure. For the two-way random effect model, this is even more so as the data cannot be decomposed into independent subunits.

\section{Testing the Random Effects}

Breush and Pagan (1980) developed the Lagrange Multiplier (LM) test (Green 2003) to test whether variance components are zero.

$$
\begin{aligned}
& H_{0}: \sigma_{g}^{2}=0 \\
& H_{a}: \sigma_{g}^{2} \neq 0
\end{aligned}
$$

Test statistic

$$
\begin{gathered}
L M_{g}=\frac{n T}{2(T-1)}\left[T^{2} \frac{\bar{e}_{g}^{T} \bar{e}_{g}}{e^{T} e}-1\right]^{2} \sim X_{(i)}^{2} \\
H_{0}: \sigma_{T}^{2}=0 \\
H_{a}: \sigma_{\mathrm{g}}^{2} \neq 0
\end{gathered}
$$

Test statistic

$$
L M_{g}=\frac{n T}{2(n-1)}\left[n^{2} \frac{\bar{e}_{g}^{T} \bar{e}_{g}}{e^{T} e}-1\right]^{2} \sim X_{(i)}^{2}
$$

Where $\bar{e}_{g}$ is the $\mathrm{n} \times 1$ vector of group-specific means of pooled regression residuals, $e_{g}^{T} e_{g}$ is the error sum of the square of the pooled regression, and $\bar{e}_{T}$ is the $T \times 1$ vector of timespecific means of pooled regression residuals.

The two-way random effect model has the following hypothesis to test,

$$
\begin{aligned}
& H_{0}: \sigma_{T}^{2}=0 \\
& H_{a}: \sigma_{g}^{2} \neq 0
\end{aligned}
$$

\section{Testing for Fixed or Random Effects}

The Hausman hypothesis test is used only for testing whether the individual random effects are correlated with explanatory variables or not. If there is a correlation between the individual random effects and the explanatory variables, it is concluded that the fixed effect estimator is consistent and efficient; however, the random effect estimator is not consistent (Hausman vs Taylor, 1981). If the null hypothesis of the Hausman test is rejected it favors the Fixed Effects estimator's treatment of the omitted effects. If the omitted effects are uncorrelated with the explanatory variables, the Random Effects estimator is consistent and efficient. However, the Fixed Effects estimator is consistent but not efficient. If the effects are correlated with the explanatory variables, the Fixed Effects estimator is consistent and efficient but the Random Effects estimator is inconsistent.

In Hausman test, the following hypotheses are tested:

$$
\begin{gathered}
H_{0}=E(\mu \mid X)=0 \\
H_{a}=E(\mu \mid X) \neq 0
\end{gathered}
$$

Where $\mu$ is the unobserved heterogeneity and $X$ is the explanatory variables. 


\section{Research Model}

In this study, the environmental accounting disclosure index is the independent variable, and the perceived performance of firms was the dependent variable which is the return on assets. Further, the firm size and liquidity are used as the control variables. The study investigates the impact of the environmental disclosure on firm performance and the model is formulated as follows.

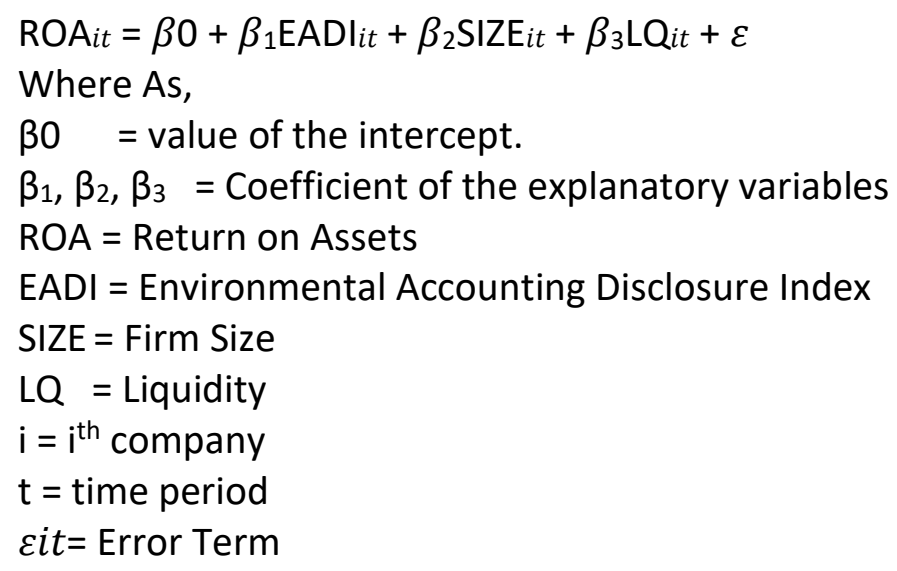

\section{Estimation and Discussions Diagnostic Tests}

Given the stationarity of the variables at level, the study finds the impact of environmental disclosure on firm performance in Sri Lanka using the pooled OLS, the fixed effect, and the random effect regression techniques. All the variables are tested for stationarity and the results of the Harris-Tzavalis unit-root test reject the null hypothesis of non-stationarity significantly at the level.

Variance Inflation Factor (VIF) close to 1 indicates that there is no correlation among the selected independent variables. If a VIF value greater than 10 indicates that there is a high multicollinearity problem. All the VIF values of the independent variables are lower than 10 and the mean VIF value is 2.71 which was below 10 . This proves that there is no multi-colinearity issue (Table 2). The study contains a micro panel with a very few periods of 8 years and the serial correlation test is not performed as they apply to macro panels with long time series over 20-30 years (Baltagi, 2012). Baltagi $(2012$, p.87) proposes to compute robust standard error-correcting for the possible presence of heteroskedasticity, and hence, the study calculates robust standard errors in both the fixed and random effects regression models to estimate the efficient regression coefficients.

\section{Fisher (F)-Test Results}

The existence of the fixed effects in residuals is tested through $F$ statistic (Table 1). The Ftest of the regression performed rejects the null hypothesis that all dummy parameters are jointly equal to zero and it may be concluded that the fixed firm effect model is better than the pooled OLS model. Hence, the fixed-effect model is the better choice than the pooled OLS regression model. In the one-way fixed time effect model and the two-way model, no significant time impacts were found and the analysis was conducted only on the one-way fixed firm and random-effects models, and the results are presented in Table 2. 
Table1: Specification Tests

\begin{tabular}{|c|c|c|c|c|}
\hline $\begin{array}{c}\text { Specifi } \\
\text { cation Test }\end{array}$ & c Statisti & P-value & Tested & $\begin{array}{l}\text { Selecti } \\
\text { on }\end{array}$ \\
\hline F-test & 1.67 & 0.03 & OLS/Fixed & Fixed \\
\hline $\begin{array}{l}\text { Breusc } \\
\text { h-Pagen }\end{array}$ & 0.05 & 0.41 & $\begin{array}{l}\text { OLS/Rand } \\
\text { om }\end{array}$ & OLS \\
\hline
\end{tabular}

Source: Survey Data, 2020

\section{Lagrange Multiplier (LM)-Test Results}

Based on the least-squares residuals, the obtained Lagrange Multiplier test statistics (Table 1) could not reject the null hypothesis; the random-effects model is favored; hence it can be concluded that the classical regression model (Pooled OLS) with a single constant term is appropriate for these data. Table 1 shows the individual company effects do not have a significant impact on firm performance variations in the Food, Beverage, and Tobacco companies in Sri Lanka hence, the fixed firm effect model is the most appropriate one.

\section{Discussion}

This study aims to examine the impact of environmental accounting disclosure on firm performance and the results of the one-way fixed (firm) effect model are given in Table 2. The results show that all three null hypotheses are rejected. First, firms that practice environmental disclosures generally show better financial performance than those that do not and there is a significant positive relationship between the extent of environmental disclosure and financial performance.

Table 2: Results of the One Way Fixed (Firm) Effect Model

\begin{tabular}{|l|c|c|c|c|c|}
\hline Variable & Coefficient & $\begin{array}{c}\text { Robust } \\
\text { Std. Error }\end{array}$ & $\begin{array}{c}\text { t- } \\
\text { Statistic }\end{array}$ & P- value & VIF \\
\hline Constant & -3.14794 & 1.41491 & -2.22 & 0.027 & \\
\hline EADI & 0.00831 & 0.00267 & 3.11 & $0.003^{*}$ & 1.31 \\
\hline LNSIZE & 0.13105 & 0.06375 & 2.06 & $0.041^{*}$ & 1.31 \\
\hline LIQUIDIT & 0.000006 & 0.00024 & 0.01 & 0.989 & 1.00 \\
\hline $\begin{array}{l}\text { Mean VIF } \\
\text { 2.21 }\end{array}$ & & & & \\
\hline \\
R squared
\end{tabular}

Note: ${ }^{* *}$ and $*$ indicate significance at $1 \%$ and $5 \%$ respectively. 
Table 2 reveals that the Environment Accounting Disclosure Index (EADI) had a positive significant $(p<0.01)$ impact on return on assets. This indicates there is enough evidence to accept hypothesis $\mathrm{H}_{1}$ which explains that the extent of environmental accounting disclosure shows a positive significant impact on firm performance. The firms that disclose more environmental information perform better than firms with less extensive environmental disclosures. The higher the extent of disclosure on environment practices the higher will be the economic performance of companies.

The positive impact of the environmental accounting disclosure on return on assets implies that the companies believe that they should engage increasingly in the utilization of resources and run operations in an environmentally friendly manner to enhance the economic performance. This supports the findings of Kassinis \& Soteriou (2003); Yakhou \& Dorweiler (2004); Bassey et al. (2013); Muhammad et al. (2015); Tasneem et al. (2016) who confirm a positive relationship between environmental accounting disclosure and return on assets. Chinedu \& Ogochukwu (2020) propose that companies with higher environment disclosure scores tend to have a higher return on assets. However, this finding is contradictory with the results reported by Najah \& Jarboui (2013); Nor et al. (2016) who find a negative relationship between environmental accounting disclosure and return on assets.

The finding also confirms the stakeholder theory of Freeman (1983) which states that the economic performance of a company affects the management's decision to engage in environmental accounting and also disclose the results. The theory asserts that managers must satisfy a variety of constituents (example, employees, customers, suppliers, local community, and so on) who can influence the firm's outcomes and guide the managers to engage in certain environmental activities in which non-financial stakeholders perceive important if not, these groups might withdraw their support from the business. Thus, managers might think that they should eliminate harmful impacts on the environment through their operations and they should make sure that they comply with environmental legislations by satisfying stakeholders' needs so that they will go long way amidst success.

The firm size which is the control variable had a significant positive relationship on return on assets at a $5 \%$ significant level. Therefore, there is enough evidence to accept the hypothesis $\mathrm{H}_{2}$ which states that the firm size positively influences on return on assets. This may be because large firms hold more resources along with strong market power that leads to earning more profits. Moreover, they depict a more socially responsible behavior than smaller firms with increased expectations from the stakeholders for large firms to act environmentally friendly way, hence it is confirmed the positive relation between firm size and return on assets. Waddock \& Graves (1997) argue that larger firms tend to be more profitable than smaller ones. Previous researchers also support this positive relationship between firm size and return on assets considering the size as a control variable (McWilliams \& Siegel, 2000; Dion \& Rui, 2014).

The results further indicate that the liquidity had an insignificant positive relationship with return on assets. Thus, the null hypothesis which states that there is a significant relationship between liquidity and firm performance could not reject, hence, there is enough evidence to conclude that liquidity is not a significant factor in explaining variation in return on assets. This shows that the higher the liquidity the higher will be the environmental 
disclosure implying companies with high levels of liquidity have a great ability to pay their short-term obligations on time as they experience strong financial conditions. However, this finding is not significant. Anyhow Kihamba (2017), finds a positive relationship between profitability measured by return on assets and environmental accounting disclosure and liquidity.

All these variables could jointly explain only a 7 percent return variation. The intra-class correlation known as rho is $\mathbf{5 8}$ percent which is the variance due to the differences across companies and the total variance due to cross-sections is (sigma u) 29 percent.

\section{Conclusion}

This study investigates the impact of environmental disclosure on firm performance in Food, Beverage, and Tobacco companies in Sri Lanka. The data were gathered for the period 2012 to 2019 from the annual reports of 26 sample companies. The environmental accounting disclosure index which was computed based on content analysis is the proxy for the independent variable and firm size and liquidity were considered as the control variables of this study. The data were analyzed using panel data regression.

The results of the best-fitted model one-way fixed firm effect model reveal that environmental accounting disclosure had a significant positive relationship with firms' return on assets. This is due to those firms that disclose their environmental activities have a high chance of increasing profits. The companies believe that they should respond largely and positively towards the environment to achieve the success and economic performance of the company. The greater level of environmental reporting enhances the customer trust and lower the reputational risks, such that create long-term shareholder value which is the prime objective of firms. Moreover, the firm size shows that there is a significant positive relationship with return on assets. Large firms have more resources, the market benefit which leads towards more profits in investing in environmental improvement activities, and large firms engage more socially responsible actions than smaller firms. Thus, larger firms become more profitable than smaller firms via making more environmentally friendly activities satisfying what the stakeholders expect and attract customers enhancing their trust thereby higher profits. The findings also reveal that liquidity is not a significant factor in explaining firm performance in Food, Beverage, and Tobacco companies in Sri Lanka.

\section{Managerial Implications}

Corporate responsibility towards environmental reporting is increasingly getting considerable attention in globally recently. A cleaner and greener environment is a must for every business to survive in the business world saving the planet. Environmental accounting reporting is not mandatory and it is voluntary in Sri Lanka hence, companies are required to increase environmental disclosures through the most accessible mean such as the annual reports in which all stakeholders can ensure such environmental disclosures more positively, thereby reducing the implicit costs on environmental problems.

The positive impact of environmental disclosure and firm performance should provide an incentive for managers to adopt environment-friendly resources/activities to satisfy the stakeholders and save the earth as well. It also recommends that firms require to accord enthusiastic emphasis on environmental reporting to achieve efficient economic 
performance making their operations to be environmentally friendly. The top management should make sure that they comply with the environmental laws as a long-term business strategy in enhancing sustainability. The higher the amount of disclosure of environmental accounting information, the greater will be the reputation and image of the businesses with stakeholders who are very keen on green growth and sustainable development.

Investors prefer to invest their funds in environmentally friendly companies as they need to be assured that the firms, they work with are more transparent and socially responsible. Besides, along with the trend of green development of the world, investors are more interested in the environmental disclosures related to the implementation of corporate social responsibility which is a mean to attract their attention. Further, they can get an understanding of investing funds in companies that have sufficient environmental disclosure that result to enhance the social responsibility and return they receive as well.

Future researchers can conduct a survey method to gather primary data and a comparative study can be undertaken to give more meaningful and realistic findings. Further, they can do a sector-wise comparison to check if any difference exists that will be more advantageous to offer a better conclusion on the relationship between environmental disclosure and firm performance.

\section{References}

Abdullah, H., Fuong, C. C. (2010). The Implementation of ISO 14001 Environmental Management System in Manufacturing Firms in Malaysia. Asian Social Science, 6 (3).

Adediran, S. A., \& Alade, S. O. (2013). The Impact Of Environmental Accounting On Corporate Performance In Nigeria. European Journal of Business and Management, 5(23), 141152.

Agbiogwu, A. A., Ihendinihu, J. U., Okafor, M. C. (2016). Impact of environmental and social costs on performance of Nigerian manufacturing companies. International Journal of Economics and Finance, 8(9):173-180.

Al-Tuwaijri, S. A., Christensen, T. E., \& Hughes, K. I. (2004). The relations among environmental disclosure, environmental performance, and economic performance: a simultaneous equations approach. Accounting, Organizations and Society, 29(5-6), 447-471. https://ideas.repec.org/a/eee/aosoci/v29y2004i5-6p447-471.html

Baltagi, B. H. (2012). Econometric analysis of panel data.Wiley, Chichester, UK. 5.

Bassey, B. E., Effiok, S. O., \& Eton, O. E. (2013). The impact of environmental accounting and reporting on organizational performance of selected oil and gas companies in Niger Delta Region of Nigeria. Research Journal of Finance and Accounting , 4(3), 57-74.

Belkaoui, A., \& Karpik, P. G. (1989). "Determinants of the corporate decision to disclose social information." Accounting, Auditing and Accountability Journal, 2(1), 36-51.

Bewley, K., \& Li, Y. (2000). Disclosure of environmental information by Canadian manufacturing companies: A voluntary disclosure perspective. Advances in Environmental Accounting and Management, 1, 201-226. https://doi.org/10.1016/S1479-3598(00)01011-6

Blacconiere, W. G., \& Patten, D. M. (1994). "Environmental disclosures, regulatory costs and changes in firm value". Journal of Accounting and Economics, 18 (3),357-377

Brammer, S. J., Brooks, C., \& Pavelin, S. (2006). Corporate Social Performance and Stock Returns: UK Evidence from Disaggregate Measures. SSRN Electronic Journal. 
https://doi.org/10.2139/ssrn.739587

Breusch, T. S., \& Pagan, A. R. (1980). The lagrange multiplier test and its applications to model specification in econometrics. Review of Economic Studies, 47 (1), 239- 253.

Burke, L., Logsdon, J. M., Mitchell, W., Reiner, M., \& Vogel, D. (1986). “Corporate community involvement in the San Francisco Bay area." California Management Review, 28(3), 122-141.

Chinedu, E. N., \& Ogochukwu, O. G. (2020). Relationship between environmental accounting disclosures and financial performance of manufacturing firms in Nigeria. International Journal in Management and Social Science, 08(02), 209-228.

Cormier, D., \& Magnan, M. (2007). The revisited contribution of environmental reporting to investors' valuation of a firm's earnings: An international perspective. Ecological Economics, 62(3-4), 613-626. https://doi.org/10.1016/j.ecolecon.2006.07.030.

Deegan, C., \& Gordon, B. (1996). "A study of the environmental disclosure practices of Australian corporations". Accounting of Management Review, 20, 65-91

Egbunike, A., \& Okoro, G. (2018). Does green accounting matter to the profitability of firms? A canonical assessment. Ekonomski Horizonti, 20(1), 17-26. https://doi.org/10.5937/ekonhor1801017e

Ezeagba, C. E., Rachael, J.-A. C., \& Chiamaka, U. (2017). Environmental Accounting Disclosures and Financial Performance: A Study of selected Food and Beverage Companies in Nigeria . International Journal of Academic Research in Business and Social Sciences, 7(9), 162-174. https://doi.org/10.6007/ijarbss/v7-i9/3315

Filbeck, G., \& Gorman, R. F. (2004). The Relationship between the environmental and financial performance of public utilities. Environmental and Resource Economics, 29(2), 137157. https://doi.org/10.1023/B:EARE.0000044602.86367.ff

Freedman, M., \& Jaggi, B. (1992). An investigation of the long-run relationship between pollution performance and economic performance: The case of pulp and paper firms. Critical Perspectives on Accounting, 3(4), 315-336. https://doi.org/10.1016/10452354(92)90024-L

Freeman, A. B. (1983). Towards an Epistemology for Radical Accounting: Beyond Objectivism and Relativism. Critical Perspective on Accounting

Gonzalez-Benito, J., \& Gonzalez-Benito, O. (2005). Environmental proactivity and business performance: An empirical analysis. Omega, 33(1), 1-15. https://doi.org/10.1016/j.omega.2004.03.002

Gray, R., Kouhy, R., \& Lavers, S. (1995). Corporate social and environmental reporting A review of the literature and a longitudinal study of UK disclosure. Accounting, Auditing \& Accountability Journal, 8(2), 47-77. https://doi.org/10.1108/09513579510146996

Green, W. H. (2003). Econometric analysis (5th ed.), Prentice Hall: Upper Saddle River, New Jersey.

Guthrie, J., \& Abeysekera, I. (2006). Content analysis of social, environmental reporting: what is new? Journal of Human Resource Costing \& Accounting, 10(2), 114-126. https://doi.org/10.1108/14013380610703120

Guthrie, J., \& Parker, L. (1990). Corporate Social Disclosure Practices; A Comparative International Analysis. Advances in Public Interest Accounting

Hackston, D., \& Milne, M. J. (1996). Some determinants of social and environmental disclosures in New Zealand companies. Accounting, Auditing \& Accountability Journal, 9(1), 77-108. https://doi.org/10.1108/09513579610109987 
Hausman, A. J., \& Taylor, E. W. (1981). Panel data and unobservable individual effects. economet- rica, 49, 1377-1398.

Hughes, S. B., Anderson, A., \& Golden, S. (2001). Corporate environmental disclosures: Are they useful in determining environmental performance? Journal of Accounting and Public Policy, 20(3), 217-240. https://doi.org/10.1016/S0278-4254(01)00031-X

Jariya, A. M. I. (2015). Environmental disclosures in annual reports of Sri Lankan Corporate: A Content Analysis. Journal of Emerging Trends in Economics and Management Sciences, 6(8), 350-357.

Joshi, P. L., Suwaidan, M. S., \& Kumar, R. (2011). Determinants of environmental disclosures by Indian industrial listed companies: An empirical study. International Journal of Accounting and Finance, 3(2), 109. https://doi.org/10.1504/ijaf.2011.043843

Kassinis, G. I., \& Soteriou, A. C. (2003). Greening the service profit chain: the impact of environmental management practices.

Kihamba, R. I. (2017). The Relationship Between Environmental Accounting And Reporting Practices And Profitability Of Manufacturing Firms Listed On The Nairobi Securities Exchange. 1-43.

Klassen, R. D., \& McLaughlin, C. P. (1996). The impact of environmental management on firm performance. Management Science, 42, 1199-1214

Konar, S., \& Cohen, M. A. (2001). Does the market value environmental performance? In Review of Economics and Statistics, 83 (2). https://doi.org/10.1162/00346530151143815

Makori, D. M., \& Jagongo, A. O. (2013). Environmental Accounting and Firm Profitability : An Empirical Analysis of Selected Firms Listed in Bombay Stock Exchange. India. Undefined.

Mahenna, Y., \& Dorweiler, V. P. (2004). Environmental Accounting: An essential component of business strategy. Business Strategy and the Environment, 13, 65-77.

McWilliams, A., \& Siegel, D. (2000). Corporate Social Responsibility and Financial Performance : Correlation or Misspecification ? Author ( $\mathrm{s}$ ): Abagail McWilliams and Donald Siegel Published by Wiley Stable URL : http://www.jstor.org/stable/3094143 Accessed : 03-05-2016 07 : 02 UTC CORPOR. Strategic Management Journal, 21(5), 603-609. https://doi.org/10.1002/(SICI)1097-0266(200005)21

Montabon, F., Sroufe, R., \& Narasimhan, R. (2007). An examination of corporate reporting, environmental management practices, and firm performance. Journal of Operations Management, 25, 998-1014

Muhammad, N., Scrimgeour, F., Reddy, K., \& Abidin, S. (2015). The relationship between environmental performance and financial performance in periods of growth and contraction: Evidence from Australian publicly listed companies. Journal of Cleaner Production, 102, 324-332. https://doi.org/10.1016/j.jclepro.2015.04.039

Najah, A., \& Jarboui, A. (2013). The Social Disclosure Impact on Corporate Financial Performance: Case of Big French Companies. International Journal Management Business Research, 3(4), 337-351.

Nor, N. M., Bahari, N. A. S., Adnan, N. A., Kamal, S. M. Q. A. S., \& Ali, I. M. (2016). The Effects of Environmental Disclosure on Financial Performance in Malaysia. Procedia Economics and Finance, 35, 117-126. https://doi.org/10.1016/s2212-5671(16)000162

O'Donovan, G. (2002). Environmental disclosures in the annual report: Extending the applicability and predictive power of legitimacy theory. In Accounting, Auditing \& 
Accountability Journal, 15 (3), 344-371. MCB UP Ltd. https://doi.org/10.1108/09513570210435870

Orlitzky, M. (2001). Does firm size confound the relationship between corporate social performance and firm financial performance? Journal of Business Ethics, 33(2), 167180. https://doi.org/10.1023/A:1017516826427

Palmer, K., Oates, W. E., \& Portney, P. R. (2018). Tightening environmental standards: The Benefit-Cost or the No-Cost paradigm? In Economic Costs and Consequences of Environmental Regulation, 9 (4), 435-448). Taylor and Francis.

https://doi.org/10.1257/jep.9.4.119

Portney, P. R., Stavins, R. N., \& Kennedy, J. F. (2000). Public Policies for Environmental Protection INTRODUCTION.

Rajapakse, B. (2002). Environmental reporting practices: Evidence from Sri Lanka. Social and Environmental Accountability Journal, 22(2), 3-4. https://doi.org/10.1080/0969160X.2002.9651676

Rajapakse, B. (2003). Environmental Reporting Practices of the Private Sector Business Organizations in Sri Lanka. In Journal of Management, 1 (1).

Rajapakse, B. (2008). Environmental Reporting: Significance and Issues: A Case from Sri Lanka. Research \& Publication Colombo University, 1-19.

Rakiv, M., Islam, F., \& Rahman, R. (2016). Environmental Accounting Reporting Disclosure and Company Profitability: A Case Study on Listed Manufacturing Companies of Bangladesh. International Journal of Ethics in Social Sciences, 4(2), 20-34.

Richardson, A. J., \& Welker, M. (2001). Social disclosure, financial disclosure, and the cost of equity capital. Accounting, Organizations and Society, 26(7-8), 597-616. https://doi.org/10.1016/S0361-3682(01)00025-3

Salama, A. (2005). "A note on the impact of environmental performance on financial performance". Structural Change and Economic Dynamics, 16, 413-21

Şenol, H., \& Ozcelik, H. (2012). The Importance of Environmental Accounting in the Context of Sustainable Development and Within IFRS Evaluation. 3rd International Symposium on Sustainable Development, 81-89.

http://oliver.efos.hr/nastavnici/nsarlija/projekti/doc/Kratak pregled Basela 2.pdf

Serrasqueiro, Z., \& Nunes, P. (2014). Determinants of capital structure: comparison of empirical evidence for the use of different estimators. Theoretical and Applied Economics.

https://www.researchgate.net/publication/267700184_Determinants_of_Capital_St ructure_Comparison_of_Empirical_Evidence_from_the_Use_of_Different_Estimator $S$

Tasneem, F., Hamza, S. M., \& Basit, A. (2016). The impact of environmental reporting on firms' performance. International Journal of Accounting \& Business Management, 4(2), 285301. https://doi.org/10.24924/ijabm/2016.11/v4.iss2/285.301

Trotman, K. (1999). "Social responsibility Disclosure by Australian Companies," The Chartered Accountant in Australia.

Ullmann, A. A. (1985). Data in Search of a Theory: A Critical Examination of the Relationships Among Social Performance, Social Disclosure, and Economic Performance of U.S. Firms. Academy of Management Review, 10(3), 540-557.

https://doi.org/10.5465/amr.1985.4278989

Waddock, S. A., \& Graves, S. B. (1997). The corporate social performance-financial performance link. Strategic Management Journal, 18, 303-319. 
Watts R. L., \& Zimmerman, J. L. (1986). Positive Accounting Theory, Englewood Cliffs: PrenticeHall.

Wiseman, J. (1982). An evaluation of environmental disclosures made in corporate annual reports. Accounting, Organizations and Society, 7(1), 53-63. https://doi.org/10.1016/0361-3682(82)90025-3

Yakhou, M., \& Dorweiler, V. P. (2004). Environmental accounting: An essential component of business strategy. Business Strategy and the Environment, 13(2), 65-77. https://doi.org/10.1002/bse.395 